\title{
Chapter 10 Government Apologies to Indigenous Peoples
}

\author{
Alice MacLachlan \\ York University \\ "Finally, we heard Canada say it is sorry." \\ Chief Phil Fontaine, Chief of the Assembly of First Nations, June 13, 2008
}

\begin{abstract}
In this paper, I explore how theorists might navigate a course between the twin dangers of piety and excess cynicism when thinking critically about state apologies, by focusing on two government apologies to indigenous peoples: namely, those made by the Australian and Canadian Prime Ministers in 2008. Both apologies are notable for several reasons: they were both issued by heads of government, and spoken on record within the space of government: the national parliaments of both countries. Furthermore, in each case, the object of the apology that which was apologized for - comes closer to disrupting the idea both countries have of themselves, and their image in the global political community, than any previous apologies made by either government. Perhaps as a result, both apologies were surrounded by celebration and controversy alike, and tracing their consequences - even in the short term - is a difficult business. We avoid excessive piety or cynicism, I argue, when we take several things into account. First, apologies have multiple functions: they narrate particular histories of wrongdoing, they express disavowal of that wrongdoing, and they commit to appropriate forms of repair or renewal. Second, the significance and the success of each function must be assessed contextually. Third, when turning to official political apologies, in particular, appropriate assessment of their capacity to disavow or to commit requires that consider apologies both as performance and as political action. While there remain significant questions regarding the practice of political apology - in particular, its relationship to practices of reparation, forgiveness and reconciliation this approach can provide a framework with which to best consider them.
\end{abstract}




\subsection{Introduction}

The year 2008 saw two historic government apologies offered to indigenous peoples, in surprisingly short succession. ${ }^{1}$ On February 13, newly elected Australian Prime Minister Kevin Rudd gave an official apology on behalf of his government (Rudd 2008) and four months later, on June 8, so did Canadian Prime Minister Stephen Harper (Harper 2008). These apologies are notable for several reasons: they were both issued by heads of government, and both spoken on record within the space of government: namely, the national parliaments of both countries. Both apologies can be traced to years of indigenous campaigning and lobbying - and in the Canadian case, to a series of lawsuits - as well as government-initiated independent investigations launched a decade earlier, which strongly recommended apology as a measure of reparation to each countries indigenous peoples, and whose recommendations had been strongly resisted by the government of the time, in each case. ${ }^{2}$

The substance of these apologies is also notable: while both refer generally to a long history of displacement, appropriation, assimilation, and inequality, they also focus on two specific government policies: the Canadian apology is addressed to former students of Indian Residential Schools, and the Australian apology reflects "in particular on the mistreatment of those who were Stolen Generations". The impact of both policies on indigenous individuals, communities and tribal cultures cannot be overestimated. In the Canadian case, the policy was explicitly articulated as a way to "get rid of the Indian problem" by "killing the Indian in the child." Young children were separated from their families and placed in church-run schools, which denied them their language and cultural practices, as well as access to the warmth of family and community. Conditions in these schools were notoriously poor, and many suffered from physical and sexual abuse at the hands of their so-called 'civilizers'. Australia's Stolen Generations have a not dissimilar story; government policy was to forcibly remove primarily 'half-caste' Aboriginal children from Aboriginal families, and place them in orphanages, group homes, or

${ }^{1}$ The Canadian apology was directed towards members of the tribes represented by the political body of the Assembly of First Nations, the Canadian Métis peoples and the Canadian Inuit people. The Australian apology identified the Aboriginal and Torres Strait Islander peoples by name. The naming of indigenous peoples is itself a contested issue, with a history of colonization, misunderstanding and racism behind it. In this paper, I will use 'aboriginal' 'indigenous' and 'native' interchangeably to describe the first peoples of the territories of present-day Canada and Australia, while recognizing that none of these is unproblematic. In doing so, I acknowledge the damage of not naming tribes and communities individually.

${ }^{2}$ Royal Commission on Aboriginal Peoples; "Bringing them Home". Both are available online: http://www.ainc-inac.gc.ca/ap/pubs/rpt/rpt-eng.asp\#chp6; http://www.humanrights.gov.au/Social_Justice/bth_report/report/index.html 
with white families. The rationale offered was that the plight of Aboriginal peoples was hopeless - they were a dying race - but that half-caste Aboriginals could be saved and, indeed, 'whitened'. As in the Canadian case, there is significant evidence that a culture of physical and sexual abuse permeated the institutions in which they were placed.

The policies and attitudes that led to the Residential Schools and the Stolen Generations were undoubtedly racist and colonial. They were also genocidal, as defined in the UN Convention on the Prevention and Punishment of Genocide in 1948, which lists "forcibly transferring children of the group to another group" as an act of genocide in Article 2. This convention was signed and ratified by both countries before either saw fit to cease their domestic policies of indigenous displacement, undermining any potential claim of ignorance regarding the wrongness of these policies. Indeed, the government of Canada did not begin to close a significant number of schools until the 1980s, and the last residential school in Canada closed as recently as $1996 .{ }^{3}$ Moreover, the collective and multigenerational traumatic impact of the seizure of children from close-knit communities cannot be overestimated. Both cases reflect Claudia Card's insight into genocide, when she notes how it includes "the harm inflicted on its victims' social vitality... its survivors lose their cultural heritage, and may even lose their intergenerational connections" (Card 11,20). The harm inflicted in these cases is not a discrete past harm; it is an ongoing one, played out in indigenous communities and families today, as the survivors of schools become parents and grandparents to children of their own. Native scholar Andrea Smith also argues forcibly for recognizing the role that widespread tolerance of sexual violence toward indigenous peoples (including children) played in genocidal policies in North America (Smith, 35-54). Although, in most cases, residential schools were run by Canadian churches and not by the Canadian state, decision to enact these policies cannot be neatly separated from the conditions they created.

In addressing these policies and acknowledging the attitudes that produced them as endemic to and representative of the history of both 'settler societies', the Canadian and Australian apologies challenge the founding myths of both states. That which is apologized for, in both cases, comes closer to disrupting the idea both countries have of themselves - and their image in the global political community - than any previous apologies made by either government. Perhaps as a result, both apologies were surrounded by celebration and controversy alike, and tracing even their short-term consequences is a difficult business.

Both are excellent examples of the burgeoning global phenomenon of the official political apology: that is, an apology offered by political representatives or heads of state, on behalf of a political body or state, for wrongs committed in the recent or the distant past. What then can we learn about the phenomenon of politi-

\footnotetext{
${ }^{3}$ Information about the history of the residential schools is available on the Assembly of First Nations website http://www.afn.ca/residentialschools/history.html (last accessed March 24, 2010).
} 
cal apologies, and how to think about and theorize them, from these two examples?

I see two dangers lurking for theorists who try to take up this question. The first is the danger of piety - that is, of being caught up in the solemnity of such ceremonial occasions, and the weight of history that they seem to carry. In the face of powerful words like 'reconciliation' and 'a new chapter', daring to critically analyze apologies can feel a little like talking in church. ${ }^{4}$ On the other side sits the danger of too-easy cynicism. Such cynicism dismisses all political apologies as cheap, 'gestural politics' awash in self-interest and crocodile tears, which enable politicians to win public acclaim and diffuse angry minority groups, without committing any actual resources to problems of injustice and exclusion (Cunningham 2004). These dangers are magnified by a certain degree of confusion regarding the nature and purpose of official political apologies: that is, what exactly qualifies as such, what role they are meant to play or what purpose they accomplish, and what criteria or standards exist for distinguishing between better or worse instances. Given the kinds of serious and longstanding wrongs for which states and governments are called upon to apologize, these questions can seem almost unanswerable; it is hard to imagine what could possibly qualify as a good or a satisfying apology.

In this paper, I explore how theorists might navigate a course between piety and cynicism in thinking critically about apologies, by focusing on these two government apologies to indigenous peoples. Such a course can be found, I argue, when we take several things into account. First, apologies have multiple functions: they narrate particular histories of wrongdoing, they express disavowal of that wrongdoing, and they commit to appropriate forms of repair or renewal. Second, the significance and the success of each function must be assessed contextually. Third, when turning to official political apologies, in particular, appropriate assessment of their capacity to disavow or to commit requires that consider apologies both as performance and as political action. While there remain significant questions regarding the practice of political apology - in particular, its relationship to practices of reparation, forgiveness and reconciliation - this approach can provide a framework with which to best consider them.

\subsection{What is an apology? What does it do?}

As apologies have become increasingly accepted in the public realm, taxonomies of apology have become increasingly complex. Theorists distinguish between col-

${ }^{4}$ Consider for example, the usually acerbic and critical Canadian columnist Rex Murphy, famous for his vigorous and spirited attacks on Canadian politicians. Murphy wrote of the Canadian apology: "the day of apology called from our sometimes all too predictable politicians a better version of themselves, gave them words and substance that may bring a hopeful new energy into play. For once, then, yes, they have the benefit of every doubt." (Murphy 2008). 
lective and individual apologies (Tavuchis 1988, 48) and between contemporaneous and retrospective apologies (Weyeneth 2001,20). They also take note of the kind of authority the apologizer is taken to have, whether representative, ceremonial, corporate or celebrity, (Nobles 2008,4) and of the identity of the individual or group demanding an apology in the first place, whether these are primary victims, their political representatives or indeed their descendants (Thompson 1992). The focus of these taxonomies is revealing: the status, import and even the function of a particular apology may vary along with the role or authority of the apologizer, the content of what is being apologized for, and the identity of the intended addressee. As these vary, so too does the meaning of the apology.

But this does not yet tell us what an apology is, in general - if indeed a singular meaning can be taken from the wealth of examples available. So, for example, an apology is something we say or utter, in speech or writing, but it is also something we offer and that we offer to someone in particular; this is part of what distinguishes apology from confession. Furthermore apologies - and certainly political apologies - are usually performed on a certain occasion, in a certain context. All of these factors contribute to whether or not we succeed in apologizing: the words we use, the timing and circumstances in which we say them, the person we offer them to, and what we are taken to be giving or offering that person in speaking at all. How ought we to go about theorizing apologies, so that we remain attentive to all these elements?

For the most part, theorists have followed J.L. Austin in thinking of apologies as speech acts, that is, social actions "that can only be done with words and, by corollary, if [they] not done in the words, [they have] not been done" (Bavelas 2004, 1). Nicolas Tavuchis refers to their "secular verbal magic" (Tavuchis 1988). But it is not clear that apologies are always done in words - and certainly, not the same words each time. In some close intimate relationships, much can be communicated with a single glance or gesture. Even in casual or formal relationships, it seems, "apologies can be communicated in a wide range of ways, through verbal statements issued publicly, joint declarations, legislative resolutions, documents and reports, legal judgments, pardon ceremonies, apology rituals, days of observance, reconciliation walks, monuments and memorials, even names bestowed on the landscape" (Weyeneth 2001, 20). But perhaps these other avenues are substitutes for words, or come to perform the function of words. If so, then apologies ultimately reduce to the communication of key propositions: "I'm sorry", "I apologize", "I was wrong" or "I hurt you", "I won't do it again".

To reduce apologies to their propositional content, even with the understanding that such content must be communicated, is to miss the extent to which apologies may be ritualistic and ceremonial, and to ignore how these non-verbal performative elements contribute to the meaning and success of the apology itself. Some theorists of apology have begun to recognize this fact. Sanderijn Cels argues that we should focus less on apologies as speech and more on apologies as performances, drawing on the resources of dramaturgical theory to interpret their cere- 
monial significance. ${ }^{5}$ Nick Smith includes also includes performance among the elements of what he calls a 'categorical apology:' to his mind, the regulative ideal guiding our various practices of apologizing (Smith 2008, 74). Finally, Mark Gibney and Erik Roxtrom argue for two non-vocal performative elements, 'publicity' and 'ceremony,' as crucial criteria for an authentic public apology (Gibney and Roxtrom 2001). There is more to the import of apologies than what gets literally communicated; this is particularly true for the examples I consider, because of their status as official apologies.

\subsection{The Functions of An Apology}

In understanding apologies as speech, Austin assigns apologies to the class of behabitives: performatives concerned with attitudes and feelings (Austin 1975, 83).

But it is far from clear that feelings and attitudes are the primary things with which apologies concern themselves. Indeed, even when we consider apologies purely as speech acts - and not more broadly, as symbolic performances or dimensions of repair - I would argue that emotions play only a secondary role in apologizing. They are not the main purpose of apologies, though they do, in many instances, play a role in conveying or guaranteeing the success of that purpose. In fact, both political and personal apologies potentially aim to accomplish five things, not all of which are necessarily a matter of emotion. Put differently, apologies have a narrative function (identifying the wrong, the wrongdoer and the victim) as well as expressing and performing the apologizer's disavowal of her past acts and her commitment to some form of repair; they are thus simultaneously backwards and forwards looking. Indeed, we can look to our examples to see how in apologizing, apologizer aims to accomplish most or all of the following five tasks:

1. She identifies an act, or series of acts that took place, and characterizes them as wrong, bad, harmful, injurious. That is, she locates the wrongdoing as such (this is not insignificant, especially in highly contested histories of events).

This can be seen in both the Australian and the Canadian apologies: in the Australian case, Rudd names the wrongfulness of past policies in the official motion, naming the "mistreatment of those who were Stolen Generations", "the removal... of children", and "the breaking up of families and communities." In the longer speech that follows the motion, he goes into detail: first describing one individual history of a woman in the audience, Nanna Nungala Fejo, then offering specific

5 This point is taken from personal correspondence with Cels. For more information on her work in progress on this topic, see http://cbuilding.org/about/bio/sanderijn-cels (last accessed March 23, 2010). 
statistics, percentages, and dates, naming the Bringing Them Home report as an authoritative source for the stories and statistics, and also quoting some of the more reprehensible articulations of the policy at various points, as evidence for its racism (Rudd 2008). The Canadian apology is shorter, but it also provides numbers, dates and other details in the very first two paragraphs, as well as the most infamous articulation of that policy, namely "to kill the Indian in the child." It also details the conditions of the schools themselves, as well as the abuse suffered, and mentions ongoing detrimental effects: "The legacy of Indian Residential Schools has contributed to social problems that continue to exist in many communities today."

2. She takes on responsibility for these events and, in doing so, accepts (or takes on, in a representative capacity) the role of the wronging party, that is, the wrongdoer.

In the case of official apologies, this is often the most controversial element, as political responsibility is closely linked both to material liability and, on occasion, to domestic or international criminal responsibility. In the Australian apology, this function emerges in two ways in the text of the official motion: first and directly, "We apologise for the laws and policies of successive Parliaments and governments that have inflicted profound grief, suffering and loss on these our fellow Australians." - and then, in the repetitive litany of "for...we say sorry," listing each harm inflicted. Rudd also forestalls any deflection of blame for past wrongs, by noting "this was happening as late as the early 1970s. The 1970s is not exactly a point in remote antiquity."7 The most blunt statement of responsibility is the fol-

\footnotetext{
${ }^{6}$ Note also how, as a potential aim of apology, this narrative function is also a point of criticism: in apologizing for specific policies, both governments succeed in avoiding the broader question of apologizing for a much longer history of genocidal appropriation and displacement.

${ }^{7}$ There is political and philosophical significance to this remark. One standard objection to official apologies concerns the difficulty of shouldering responsibility for distant injustices - and indeed, of applying contemporary moral standards to past eras. In his response to Rudd's motion, Australian Liberal Leader Brendan Nelson emphasized, "our generation does not own these actions, nor should it feel guilt for what was done in many, but not all cases, with the best of intentions" (Nelson 2008). Indeed, former PM John Howard refused to apologize for precisely these reasons: he argued that because the policies leading to the Stolen Generations did not violate domestic or international laws of their time, and did not constitute gross human rights violations, they should not be judged by contemporary standards (Nobles 2008, 96). To do so would be to inflict a kind of chronological colonialism of our own, he claimed, via the unfair imposition of alien moral standards. Rudd's history reminds his audience that the era of the Stolen Genera-
} 
lowing: "The uncomfortable truth for us all is that the parliaments of the nation, individually and collectively, enacted statutes and delegated authority under those statutes that made the forced removal of children on racial grounds fully lawful" (Rudd 2008).

In this aspect, the Canadian apology is both less detailed and more equivocal. At first, Harper states: "In the 1870s, the federal government, partly in order to meet its obligation to educate Aboriginal children, began to play a role in the development and administration of these schools." Two phrases lessen the extent to which responsibility is taken: the reference to meeting an obligation (which sounds like an excusing or a justifying condition) and the idea of "playing a role". While it is true that the schools were administered by the churches and only overseen by the government, this has the effect of seeming to 'split hairs' regarding responsibility for the policies. Luckily, the statement continues with a more accurate assertion of responsibility: "The Government of Canada built an education system in which very young children were often forcibly removed from their homes". Furthermore, it is not only the policies that must be acknowledged as wrongful, but the worldview that motivated them: since, "these objectives were based on the assumption Aboriginal cultures and spiritual beliefs were inferior and unequal" (Harper 2008).

3. She acknowledges what she takes to be the effect of her acts on the addressee or recipient of her apology; that is, she locates the addressee as the wronged party or victim.

It might seem that the effects of the forcible removal of children, the separation of families and communities, and the systematic devaluing and destruction of a culture are obvious, and not in need of emphasis. But this is far from true: indeed, official apologies can play a crucial role in ceasing (or curbing) formal and informal practices of victim-blaming. In these examples, the present states of indigenous communities, still reeling from collective trauma, are taken out of their causal and historical contexts (not to mention ongoing systemic injustice). In the case of the Canadian apology, for example, the experience was very nearly marred by the radio comments of a parliamentary secretary in Harper's government, Pierre Poilievre, MP for Nepean-Carleton, who suggested just hours beforehand that the apology and subsequent reparations were wasted money, and that Canadians would do better to "engender the values of hard work and independence and selfreliance" in indigenous communities. ${ }^{8}$ The 1996 Royal Commission on Aboriginal Peoples had emphasized, in its recommendations, how "acknowledging responsi-

tions is not alien. Australia's signature on the UN Convention also undermines Howard's position.

${ }^{8} \mathrm{Mr}$ Poilievre subsequently apologized for his remarks in the House of Commons. See http://www.cbc.ca/canada/story/2008/06/12/poilievre-aboriginals.html (accessed March 25, 2010). 
bility assists in the healing process because it creates room for dialogue" (Govier and Prager 2003, 68). Rudd's speech describes these effects quite viscerally, in discussing the stories captured in the Bringing Them Home report:

"The pain is searing; it screams from the pages. The hurt, the humiliation, the degradation and the sheer brutality of the act of physically separating a mother from her children is a deep assault on our senses and on our most elemental humanity" (Rudd 2008).

Harper is more circumspect, and - again - not without equivocation:

"The government now recognizes that the consequences of the Indian Residential Schools policy were profoundly negative and that this policy has had a lasting and damaging impact on Aboriginal culture, heritage and language. While some former students have spoken positively about their experiences at residential schools, these stories are far overshadowed by tragic accounts of the emotional, physical and sexual abuse and neglect of helpless children, and their separation from powerless families and communities" (Harper 2008, italics added).

There is a very real sense in which this nested minority report misses the point: the wrongness of the residential schools policy cannot be measured in terms of individual student satisfaction. Even if a majority of students had spoken positively, there is a very real sense in which the policy would still have been wrong. In qualifying his description of the effects of the schools, Harper undermines the recognition mentioned above, namely, that the residential schools were wrong in objective as well as in practice. Furthermore, in alluding to a wide range of experiences at the schools, he also subtly displaces top-down responsibility, hinting that the bad experiences of some - or most - might well be attributed to particularly abusive 'bad apples' in the schools themselves, and not a bad system. Finally, while there may be some appropriate time to celebrate the experiences of happier survivors, an official apology is simply not that moment. Of course, the Canadian apology does acknowledge suffering survivors, as the appropriate recipients of acknowledgment, in a slightly different manner:

"It has taken extraordinary courage for the thousands of survivors that have come forward to speak publicly about the abuse they suffered. It is a testament to their resilience as individuals and to the strength of their cultures."

\footnotetext{
${ }^{9}$ This resembles a feature that, in his discussion of apologies, Louis Kort describes as a "gesture of respect" - additional words acknowledging the victim's perspective, or some further indication of respect that counteracts the initial disrespect conveyed by the wrong itself (Kort 1975).
} 
This acknowledgement is especially significant, since it notes how the burden of a culture of silence was also inflicted on survivors; it was left to them to come forward, to initiate justice, to demand what was rightly theirs. Harper goes on to say, "the burden of this experience has been on your shoulders for far too long. The burden is properly ours as a Government and as a country." In other words, the absence of an apology and gestures of reparation - up until this point - is itself an ongoing source of grievance and pain.

4. She disavows her acts as wrongful. This may include expressions of remorse, agent-regret, guilt or shame. It may involve the identification of individual wrongs, and explanations of why they are wrong (thus demonstrating an appropriate attitude to these wrongs in particular, and wrong acts or policies in general).

Disavowal and repentance are a complicated business. To fully take responsibility for the act, the agent must identify herself with the wrongdoings in some way, that is, she must own them. And yet - to disavow these acts - she must distance herself from them. At least in our interpersonal relationships with others, we achieve disavowal and distance from past actions in part through our attitudes towards them. We experience and express remorse, guilt and shame, and the others test and measure our disavowal by the sincerity of these expressions.

Of course, attitudes can be misleading, as Alice learns in hearing the story of the Walrus and the Carpenter (who lured and ate a number of oysters) from Tweedledum and Tweedledee, in Lewis Carroll's Through the Looking Glass.

"I like the Walrus best," said Alice, "because you see he was a little sorry for the poor oysters."

"He ate more than the Carpenter, though," said Tweedledee. "You see he held his handkerchief in front, so that the Carpenter couldn't count how many he took: contrariwise."

"That was mean!" Alice said indignantly. "Then I like the Carpenter best--if he didn't eat so many as the Walrus."

"But he ate as many as he could get," said Tweedledum.

This was a puzzler. After a pause, Alice began, "Well! They were both very unpleasant characters-_-" (Carroll 1960, 237). ${ }^{10}$

${ }^{10}$ In the edition of The Looking Glass annotated by logician Martin Gardner, Gardner somewhat officiously informs the reader in a footnote that in fact, Alice is puzzled because she faces the familiar dilemma of judging someone by their acts or their intentions. This footnote has always bothered me. Both the Walrus and Carpenter had fairly devious intentions and abhorrent actions (at least from an oyster-sympathizer's perspective). Instead, Alice seems unsure about the end of the story: that is, their reactions in the aftermath of the crime - especially given Tweedledee and Tweedledums' narrative additions and adjustments. What lies in 
Clearly, the wrongdoer's actual behavior also plays a crucial role in disavowal. But in interpersonal contexts, at least, feelings and attitudes cannot be discounted; most victims would regard a perfectly well behaved and reformed wrongdoer who nonetheless experienced no regret with suspicion and hostility.

Feelings and attitudes cannot play the same role in official apologies as they do in interpersonal apologies, though this does not mean public figures have been unwilling to exploit them. Apology politics have emerged, in part, alongside a new 'self-reflexive' approach to political leadership, exemplified by charismatic figures like Presidents Bill Clinton and Barack Obama, or Prime Minister Tony Blair. Leaders are more willing to bare their souls, and their emotions: on camera, on talk shows, or on paper. Nevertheless, the irony of this supposedly 'personal' style of politics is apparent in an exhibit by Canadian artist Cathy Busby, titled Sorry. The exhibit consists of extremely large photographic prints of politician's mouths, captures whilst 'baring their souls' in apology (in these cases, usually for their own, individual misdeeds). In these photographs, the intimacy of the personal - here, represented visually by the close-up on a face - is hyper-accelerated by a camera that has zoomed in too far. Visual intimacy in extremis actually robs the speaker of recognizable identity, and thus of personhood: a mouth is just a mouth after all. Lined next to one another on display, the apologizers are uniform, faceless, and anonymous. Busby's images are far more impersonal than photographs taken at a distance, such as traditional formal photos of government officials engaged in formal treaty negotiation, and the 'souls' that are supposedly bared are revealed so intimately that they become utterly soul-less. The text of each apology is printed only in excerpts: the artist's comment on style over substance in the modern practice of political apology. ${ }^{11}$

The sense that personal emotions have no place is compounded when the apology is official. The acknowledgment, disavowal and commitment necessary for a successful political apology cannot depend merely on the sentiments and feelings

question is not the intention or action of the wrongdoers, but their stance following the wrongdoing - and, more broadly, what we do or do not want to see in a story of wrongdoing.

${ }^{11}$ Busby references both individual and official apologies, by both political and other public figures, and almost all her examples are for contemporaneous not retrospective apologies. www.cathybusby.ca/sorry/ (accessed March 17, 2009). Interestingly, Busby has chosen to represent the two apologies I focus on today very differently: in her latest exhibits, Righting the Wrongs and We are Sorry, Busby has imposed the texts of the apologies by the Canadian and Australian Prime Ministers along the front or side of public buildings. The effect is very different from that of Sorry: the words of contrition literally cover the public face of a public building, suggesting that, in these cases, perhaps substance has trumped style [reproductions of Righting the Wrongs and We are Sorry received from private correspondence with the artist]. 
of the individual(s) who will utter it. Whether or not the Canadian government faces its responsibility for a legacy of residential schools will not depend on PM Stephen Harper's inner life. The appearance of the wrong emotional tone can certainly cause a political apology to misfire, but it is not clear that the right tone can guarantee its success.

In the absence of interpersonal feelings and attitudes, what appropriate moral motivation is there to drive political apologies? The cynical answer is, of course, that they lose meaning qua apologies altogether: because they are public, formal and pre-negotiated, they are empty gestures. This cynicism is not limited to academics and media commentators. Consider the following somewhat representative response to the Canadian government's apology, taken from an online news forum:

"I can't believe it! Some of you are complaining that the apology didn't have enough "emotion." What the heck did you want the [Prime Minister] to do... get all misty eyed and start crying/talking as he gave his speech... Many of these comments are made from people who can't see the reality of the [public relations] value of this apology. The apology garners [sic] PC party support during the next election. Also the [sic] PC party made the apology because it was the politically correct thing to do... THAT'S IT." 12

Should we endorse this commentator's assessment of the Canadian apology? Certainly, it is true that the motivations of political actors may be more complex than those of private individuals: politicians are elected to serve the interests of their constituents, after all, and not always for some wider moral purpose. Furthermore, their own interests are very much bound up in continuing to serve that purpose, through re-election. Official apologies are the result of complex negotiations and calculations. For this reason, we do better if we do not model political apologies too closely on the personal and emotional qualities of apologies made by individuals (Thompson 2008, 36), but look to other measurements of disavowal, based on their nature as official acts.

In some sense, even uttering the word "apology" is a kind of disavowal. Governments, unlike the Catholic Pope, do not claim infallibility - but neither are they known for rushing to admit mistakes. Harper says "apology" twice in his speech, "apologize" four times, and "sorry" once. Rudd, in his longer speech, says "apology" fourteen times, "apologise" five times, and "sorry" nine times. Unlike the Canadian government's previous 1998 "Statement of Reconciliation" or the previous Australian government's policy of "practical reconciliation" both aim at the idea

12 The comment wrongly identifies the governing party of Stephen Harper as the (now defunct) Progressive Conservative party, rather than the present-day Conservative Party of Canada. Posted by commonsenseman, 2008/06/12 at 1.12 PM ET, $\quad$ http://www.cbc.ca/canada/story/2008/06/11/pmstatement.html\#articlecomments (accessed March 12, 2009). 
of apologizing, explicitly. ${ }^{13}$ While this effect may fade as the 'age of apology' continues, it is still the case that government apologies possess sufficient novelty for this act, in itself, to indicate an important change of stance and policy.

Furthermore, the authoritative articulation of right values can itself function as disavowal of widespread wrong values (Harvey 1995). In describing Australian Aboriginals as "a proud people... and a proud culture," Rudd refuses to endorse stereotypes to the contrary. In identifying "reconciliation" as the expression of a "core value of our nation - ... the value of a fair go for all", and noting that a "fair go" was not had by the Aboriginals, Rudd - in his leadership capacity - puts the lie to any story to the contrary. Rudd describes collective encounter with "the cold, confronting, uncomfortable truth" of Australia's history as the "wrestling with our own soul" and insists that as far as reconciliation and justice are concerned, "old approaches are not working." Thomas Brudholm writes, "a kind of reconciliation between peoples can build on a common refusal of reconciliation with the past" (Brudholm 2008, 116). Rudd's speech returns, again and again, to the idea that the past has not passed, in many significant senses, that it remains something to be "wrestled with" and repaired. In refusing either to reconcile with the past, his words do much to disavow it.

Harper's apology relies partly on the image of a journey to express his disavowal: "You have been working on recovering from this experience for a long time and in a very real sense, we are now joining you on this journey." There is an appropriate humility in this expression. The metaphor is not unproblematic, however; Harper says, four times, "the Government of Canada now recognizes that it was wrong" or "we now recognize that it was wrong", implying that Canadian failures were ones of (possibly culpable) moral ignorance and not knowing wrongdoing. Yet the "Royal Commission on Aboriginal Peoples" (1996) documents available testimony and evidence dating back to the early days of both policies, indicating the generally poor conditions at state-run schools and orphanages. In a 1907 report, for example, the Canadian Indian Affairs' chief medical officer admitted, " $50 \%$ of the children who passed through these schools did not live to benefit from the education which they have received therein" (Rolfsen 2009, 30). In other words, disavowal must be balanced with responsibility for both to avoid appearing disingenuous.

The final element of an apology is the most forward-looking. Not coincidentally, it is also the element that resists analysis in terms of speech. For commitment in particular, it seems, contra Bavelas, apologies cannot be done only with words at all. The fifth function an apology may aim to perform is as follows:

${ }^{13}$ The previous Australian Prime Minister, John Howard, consistently refused to issue an apology for the "Stolen Generations", and instead advocated pursuing a policy of 'Practical Reconciliation': a vision of formal equality with no distinctions in citizenship, with involved no land claims, no self-governance and few special rights for Aboriginal Australians, and which took no responsibility for the policies of past governments. 
5. She commits herself to a future in which apologies are not necessary; that is, she commits herself to further appropriate acts and attitudes on her part ("I won't do it again"). If appropriate, she may also indicate a willingness to change things for the wronged party, either through amends and compensation, further gestures of respect, or perhaps the initiation of a more appropriate moral relationship.

Both Rudd and Harper make commitments to a different future between indigenous and non-indigenous citizens, in their official apologies. Rudd speaks of a new "partnership" aimed at the very practical goals of closing the gap in life expectancy, literacy, numeracy, employment outcomes and opportunities - and sets some concrete goals for childhood health and education. He also proposes that the commission established to achieve this might consider "the further task of constitutional recognition of the first Australians", suggesting a commitment to both symbolic and material change. Harper's commitments on behalf of his government are perhaps less voluntary, since they originate in the settlement agreement from a lawsuit, but he also refers to the implementation of this agreement as a new "partnership." Indeed, the agreement included individual compensation packages, support for a general "healing fund" and other forms of commemoration, as well as a $\$ 60$ million Truth and Reconciliation Commission, dedicated to uncovering the history of Indian Residential Schools, and making these stories known to nonIndigenous Canadians. ${ }^{14}$ The commitments listed are not only practical; in naming aspects of the new partnership, Harper gestures towards "a relationship based on the knowledge of our shared history, a respect for each other, and a desire to move forward together with a renewed understanding that strong families, strong communities and vibrant cultures and traditions will contribute to a stronger Canada for all of us."

\subsection{Assessing Apologies}

As I mentioned above, my purpose in itemizing these features has been to demonstrate a given apology may have multiple purposes. First, there is a narrative purpose: apologies identify the wrongdoing as such, the apologizer as responsible for it, and the victim or addressee as wrongfully harmed by it. Second, apologies communicate and even demonstrate disavowal; in apologizing, the wrongdoer distances herself from her acts even as she takes responsibility for

\footnotetext{
${ }^{14}$ In terms of individual compensation, the settlement specifies $\$ 10,000$ for each student who attended a Residential School, with $\$ 3000$ for each subsequent year of school. Individual settlements with survivors of sexual and physical abuse will be negotiated beyond these lump sums. To my mind, the Truth and Reconciliation Commission is one of the most exciting aspects of the settlement agreement and subsequent apology.
} 
them, repudiating the attitudes, motivations, and circumstances that led her to perform them. Finally, apologies represent a form of commitment, both to the apologizer's ongoing disavowal and her good-faith efforts to repair the wrongs as she is able and as is appropriate. Feelings and attitudes only appear as the vehicles for these primary functions. Remorse and guilt can communicate a sense of wrongdoing and acknowledgment of its effects; such attitudes also motivate our desire to disavow past wrongs, and our intentions to be and behave otherwise, and to repair past wrongs.

Not every element I have described is fore-grounded and explicit in every apologetic utterance - in our everyday lives, there is much we can take for granted or communicate non-verbally. But an utterance that failed even to imply any of these five things, or implied their opposite, would not be recognizable as an apology; collectively, they shape the boundaries of our recognizable practices of apology, even if instances of apology within those boundaries share only a family resemblance to one another. These features help us to distinguish apologies from close cousins like confessions, which need not identify the addressee as a victim, expressions of sympathy ("I'm sorry you feel that way"), which do not necessarily identify the speaker as the wrongdoer or the act as wrong, or even rueful or unrepentant admissions of fault ("I guess that's just the way I am"), which fail to perform the distancing function of disavowal.

Indeed, we can see just how each of these elements functions in locating practices of apology, if we consider a speech widely recognized to be a failure of apology: namely, the 1998 Canadian "Statement of Reconciliation." 15 Unlike the two 2008 examples, Stewart never utters the words "apology" or "apologize" and her single use of "sorry" is questionable. She does identify the wrongful harms of the past and their effects on indigenous culture and peoples, but both the second and fourth elements, i.e. taking responsibility as wrongdoer and disavowing past acts, are arguably absent. Stewart says that Canada must "recognize" and "acknowledge" the effects of its history, and she formally expresses "regret" at the actions of past governments, but that regret is never transformed into the admittedly stronger terms of "responsibility," "remorse" or even "guilt." The statement rather puzzlingly tells survivors of residential schools that "we wish to emphasize that what you experienced was not your fault and should never have happened," a remark which - in this context - is almost patronizing, since it does not go on to take on that same fault (responsibility). While the statement does say, "to those of you who suffered this tragedy at residential schools, we are deeply sorry," the word 'sorry' in this context is highly ambivalent and, it appears, intentionally so; it could express remorse, but equally, it could be merely sympathetic. Similarly, the use of "reconciliation" without responsibility has the effect of suggesting a purely forward-looking approach, or hints that past relationships have faltered because of mutual misunderstanding and not because of an asymmetrical relation-

\footnotetext{
${ }^{15}$ For a discussion of 'non-apologies' and 'quasi-apologies' in the Canadian con-
} text, see the contribution by Matt James in Gibney et al (2008). 
ship of injustice or oppression. It is hardly surprising that in Chief Fontaine's response to the 2008 apology, ten years later, he emphasizes, "finally, we heard Canada say it is sorry" (Fontaine 2008).

Of the elements of an apology, the fifth and final - commitment - is perhaps the most contentious. There are certainly interpersonal apologies that fail to communicate this element, or to communicate it sincerely, while still being recognizable as apologies. In the case of chronic re-offenders, who know they cannot in good conscience promise to be different, but nonetheless acknowledge and disavow their behavior - no doubt experiencing a high degree of self-loathing and alienation as a result - we may recognize the helpless "I wish I could say I won't do it again, but I can't" as a kind of apology, albeit one marred by self-conflict and moral dissonance. What is interesting in these cases is that the apologizer appears to be apologizing for who she is, and no longer what she has done. ${ }^{16}$ Indeed, this may explain why official apologies, unlike interpersonal apologies, are held to stricter standards of commitment: we have little sympathy for a chronically reoffending state, and would have trouble understanding what it meant that such a state simply could not subject itself to appropriate reforms and reparation.

Thus, I would suggest that when we approach the assessment of apologies (in any context), it is important first to take into account what Austin's categorization overlooks: namely their narrative and their commissive functions. Apologies have a historical or recording function; they tell a particular kind of story about the events apologized for, and the participants' role in them. They also have a futureoriented commissive function; in apologizing, I often implicitly or explicitly attempt to persuade you that I am not likely to do this again - indeed, that I am not the kind of person to do this again. In political and in personal contexts of contested histories and the ongoing need for mutually acceptable coexistence, these may come to play a primary role in the success and assessment of the apology itself.

Furthermore, the fact that apologies have multiple functions is significant for their assessment. It is not clear that each element of the apology, or its purpose, will be equally important in all cases. So, for example, where there is significant dispute over what actually took place or when the apology follows a long period of time in which the wrongs were covered over or denied, the most important aspect of the apology for all concerned may be its narrative function: getting clear on who did what, to whom, and when. In other instances, when these details are not in dispute, the roles of disavowal or commitment may come to the fore.

The measurement of each potential function will be highly particularistic; what counts as an appropriate narrative, or a satisfying expression of disavowal, or even a sufficient commitment for the future, will depend on the nature and extent of the wrong, the pre-existing relationship between apologizer and recipient, and other features of the context, including broader social norms surrounding social status, the taking of responsibility, rituals of apology and acceptable moral relationships. The upshot of these two features - the multiple functions of apologies and the con-

${ }^{16}$ For an interesting and related discussion, see Bell (2008). 
textual way in which these functions apply - is that there is no overarching singular standard, that is, an 'ideal', 'paradigmatic' or 'categorical' apology against which all individual apologies ought to be measured. ${ }^{17}$ Our practices of apologizing are simply too varied, and the norms they obey too tied to contextual features, for such an ideal to function fairly and universally.

\subsection{Assessing Official Apologies: Some Complications}

Are there aspects of official apologies, beyond their multiple and contextual functions - a feature they share with interpersonal apologies, after all - that prevent us from easily assessing them? Why is it harder to pick out appropriate measures of narration, disavowal and commitment in political contexts? Certainly, government apologies, like individual apologies, can recount appropriate narratives of wrong, responsibility and harm. Both the Australian and the Canadian example employed narrative imagery in their opening phrases: Harper described the Residential Schools as a "sad chapter" and Rudd a "dark chapter". Rudd also resolved, "that this new page in the history of our great continent can now be written." Few Canadians had challenged so-called 'common wisdom' (i.e. gross stereotypes and misunderstandings) about poverty, laziness, and substance addiction in Native communities - or connected it to the fact that a generation of sexual-abuse survivors, isolated from all their cultural and community resources as children, is now raising a second generation of children themselves (Rolfsen 2008, 31). Chief Fontaine noted that following the apology, $73 \%$ of Canadians surveyed were aware of the apology, and of those, $83 \%$ supported it (Fontaine 2008b). ${ }^{18}$ The apologies, in naming the wrongs done to generations of indigenous children, succeed in re-

\footnotetext{
${ }^{17}$ Here I part ways from two recent influential treatments of the topic: Charles Griswold's (2007) treatment of apologies Nick Smith's concept of the categorical apology as normative ideal (Smith 2008).

${ }^{18}$ Several indigenous commentators on a comment thread on the CBC news website echoed this sentiment: the most moving aspect of the apology was that, for the first time, their non-indigenous friends and neighbors were curious about residential schools and their experiences. See comments posted at http://www.cbc.ca/canada/story/2008/06/11/pm-statement.html. When asked by journalist Rolfsen what white Canadians can do "to repair what's broken?" Canadian Aboriginal Lyana Patrick answered, "Listening would be great. Listening would be great." (Rolfsen, 32).
} 
counting their history. ${ }^{19}$ Indeed, testimonial responses to the Australian apology emphasized this acknowledgment. ${ }^{20}$

More contentious are the latter two functions: it is not clear what plays the analogous role in political life that feelings and attitudes do in personal relationships. What appropriately demonstrates the disavowal and commitment of a government, rather than of a single individual? What would give us reason to trust or to doubt the motivations behind expressions of disavowal and commitment made by Rudd and Harper? Plausible candidates include the success of the material compensation and commitments offered, the effect of changes to the historical record, the affective responses of addressees and witnesses, or perhaps whatever renegotiated political relationship emerges from those initial responses.

Material compensation appears to be an obvious source of measurement; as some have argued, "questions of social justice and legal liability cannot and should not be separated" (MacDuff, 1). Indigenous groups criticized the Australian government for not attaching a compensation package to the apology. ${ }^{21}$ While the Canadian government's apology was issued alongside material reparations payments and a comprehensive settlement agreement, it was also expressed by a government who had recently slashed funding to First Nations communities, rejected the Kelowna accord, promising \$1billion for anti-poverty initiatives, mental health programs and clean water, and signed by the previous, less overtly apologetic, government, and they stalled a number of land claims negotiations. If we look to material measurements of apology, the verdict is still out on whether either apology has successfully disavowed the past or lived up to its promised commitments.

19 That it was a government and not an indigenous voice who successfully recounted the history raises entirely different questions of appropriation and silencing. But it is important to remember that when governments tell stories, they get heard.

${ }^{20}$ One woman recounted how she remembered being identified by number and not name in a state-run orphanage, given an arbitrary collective birthday and a uniform token present. She notes the apology with its emphasis on survivor stories was "a final kind of recognition that I exist. My name is Veronica Ann McDonald." http://www.qldstories.slq.qld.gov.au/home/digital_stories/apology_responses 21 "In fact, that there has been a denial of any [sic] monetary or any compensation that has been talked about in our country, I think is a blight on our history. I think it is morally correct to offer some olive branch here in terms of compensation." Jackie Huggins, deputy director of Aboriginal and Torres Strait Islander Studies at the University of Queensland and a former co-chair of Reconciliation Australia, http://www.abc.net.au/news/stories/2008/02/13/2161979.htm (accessed March 19, 2009). 
On the other hand, the scope of political responsibility is not exhausted by notions of legal liability or rectificatory compensation. ${ }^{22}$ Neither can the significance of an apology cannot be reduced to its attached reparations; after all, there are victims who reject reparations unless accompanied by some form of apology. The symbolic features of apology matter as much as the material features do.

Both Aboriginal and non-Aboriginal Canadians commented consistently that the most moving aspect of the apology was the sight of Chief Phil Fontaine of the Assembly of First Nations (the political body representing over 50 native tribes) standing on the floor of the parliament in full ceremonial headdress, alongside leaders from Canada's Métis and Inuit populations. This was the first time native leaders had been overtly invited onto the floor of the house in their capacity as representatives of nations, and had been granted permission to speak in that capacity. As one commentator remarked, "Never discount the energy and communicative power of symbolism and ceremony. Chief Fontaine's speech was a power in itself, the best of the day... Wearing the appurtenances of his office, standing in that chamber, in the company of other aboriginal leaders... he embodied the occasion" (Murphy 2008).

Receiving and responding to a formal apology, when that was understood as a gesture between political bodies and peoples, not individuals, cemented recognition in Canadian consciousness that the Assembly of First Nations was a political body, deserving of formal address, in a way that expressions of feelings could not do alone. ${ }^{23}$ In a later speech, Chief Fontaine spoke movingly of what it meant "to be on the floor of the House of Commons - to speak in one's own voice, in one's own right (capacity) to the country..." (Fontaine 2008b). In other words, it wasn't the speech - or the speaking - of apology itself that achieved the third function, that of recognizing and acknowledging the apology's addressee. The recognition required, in this instance, was symbolic and political. It could only be achieved by the apology as public ceremony. Since part of the harm done to Canada's indigenous peoples had been the refusal of such recognition, this also represented (at least) symbolic disavowal of past policies of paternalism and disrespect.

${ }^{22}$ In fact, because the responsibility and recognition expressed in apologies is not necessary tied to material compensation, even those who reject the idea of historical reparations may still accept apologetic or symbolic gestures. Jeremy Waldron - who famously argued that commitments to present-day distributive justice supercede the claims of historic injustice - acknowledges that his point applies only to proportionate reparation payments understood as rectificatory justice. Smaller payments attached to apology or other symbolic gestures "symbolize a society's undertaking not to forget or deny that a particular justice took place" (Waldron 1992, 6).

${ }^{23}$ Perhaps for this very reason, whether or not the native leaders would be allowed to speak from the floor was a hotly contested issue, almost until the last minute. It was largely because of the intervention of an opposition party - the left-leaning New Democratic Party - the government eventually relented. 
Measuring the need for symbolic gestures of reparation against material and financial is difficult. There is understandable fear that, unless apologies are necessarily tied to reparations, the symbolic nature of apology replaces or circumvents other material efforts to repair damage. Of course, this only holds true if apologies are taken to be a complete response to historic injustice in themselves, and not a component of a broader project, indeed, a component that can actually bind governments to further action. If part of what an apology accomplishes is commitment, then we are right to measure the success of apology in part by what exactly is committed. In both these cases, that commitment was in part material, and unfortunately, it remains very much in question.

Recognizing the functions of an apology and learning to evaluate them in terms of those functions is not a guarantee that every good or successful apology is without political risk. For one thing, an apology is, by definition, a wrongdoer's narrative, and thus it remains to some extent within the wrongdoer's control. She still controls the story being told, even if that story involves her best effort to sympathetically incorporate and acknowledge the victim's perspective. Even the most well-intentioned of wrongdoers will dwell just a little too long on the state of their own soul, while castigating it; there is something peculiarly narcissistic in a toorepentant apologizer. ${ }^{24}$ Furthermore, an apology does not simply perform one's (prior) guiltiness. Through the ability to narrate that wrongfulness as wrong, and through the expression of disavowal and one's commitment to that disavowal, it also performs one's (current) rightfulness - or at least, one's right thinking-ness. As Elizabeth Spelman says, apology is a vehicle "for vice nested in virtue", and it allows the apologizer to "wrap herself in a glorious mantle of rehabilitation" (Spelman 2002, 96-97). In doing so, apologies may redirect us from - and even foreclose - other investigations into the misdeeds and motivations of the past, shutting down further inquiry.

Finally, while the call for apology demands something of the wrongdoer, the apology itself may return that demand to the victim. The Canadian apology asks "... the forgiveness of the Aboriginal peoples of this land for failing them so profoundly". This request jars with the earlier, humbler acknowledgment that nonindigenous Canadians have only just joined indigenous survivors on a journey of recovery - forgiveness, if relevant at all, seems a little premature. It is telling that Chief Fontaine's eloquent response bears no mention of the word forgiveness. While he ends by reaching out to all Canadians in a spirit of reconciliation, he does so by noting: "we still have to struggle." Rudd's speech makes no mention of forgiveness, although he asks that, "the apology be received in the spirit in which it is offered" and further, he states, "it is time to reconcile."

${ }^{24}$ Columnist Salutin described how, leading up to the 2008 apology, "there was a smug sense on the part of some apologizers that it's all about us. CTV's Dan Matheson asked Mike Duffy, 'Do you think we are ready as a people to say we are guilty?' 'Oh I think we are, Dan' cogitated Duff' - much like sports commentators assessing our chances for making the playoffs this year (2008). 
Grasping this danger requires that we reflect on the differences between requesting or even demanding a response, on the one hand, and providing an opportunity to be heard, on the other. After all, the chance to respond is sometimes a relief to victims. Precluding a response from the victims is just as much a danger for official apologies, if the apologizer is given the last public word on the subject. The apology then reinforces the original harm of silence, exclusion and being spoken for. One Australian columnist remarked,

"Throughout the coverage of the apology, I couldn't shake the sense that the indigenous Australians included in the televised spectacle - whether invited guests in Parliament House or the dozens of emotion-filled faces from around the country - were little more than props. Their role was to express and register the emotional content of the event. But the apology was not intended for them. The true recipients of the apology were those white Australians who watched and wanted to be made to feel as if they had taken part in something good..."25

The most contested aspect of the Canadian apology was the last-minute negotiations to allow the Chiefs to speak from the floor of the Parliament. In both cases, it seems, the danger was not the demand for a response, but the refusal to allow one. Recounting one's sins may provide an inner glow, but listening to someone else recount them is far more uncomfortable. There was a distinct and collective intake of breath in Canada, when Chief Fontaine said "racist policy".

One final danger of political apologies emerges from their narrative power and their potential character as already-identified stories of closure and change. Both government apologies mention "new partnerships" between Aboriginals and nonAboriginals, going forward. Yet the language of reconciliation, often appealed to in apology, suggests the revitalization of an old relationship, not the beginning of a new one. In Harper's apology, the first mention of the word 'apology' is: "The government recognizes that the absence of an apology has been an impediment to healing and reconciliation," and in the final paragraph "healing, reconciliation and resolution" are named as the express goals of the settlement agreement. But as Gerry Oleman, a residential school survivor and community support worker remarks, "I think reconciliation is the wrong word. When have we been in harmony? I don't think we've had a relationship we're going to mend" (Rolfsen 2008, 30). Thus the value of both apologies may depend to a large extent on how new the relationship forged really is: as measured out in political and civic recognition, and in equal conditions and opportunities for civic life and cultural flourishing.

25 Scott Stephens, "The Apology and the Moral Significance of Guilt," http://www.abc.net.au/news/stories/2008/02/25/2171795.htm (accessed March 20, 2009) 


\subsection{Conclusions: Apologies and their Aftermath}

It seems unlikely that we will ever have purely theoretical grounds for judging one apology an unqualified success, morally or politically speaking, and another a failure. In this paper, I have focused on two recent apologies by heads of government and directed towards representative bodies of each nation's indigenous peoples. Moreover, I have argued, these two examples demonstrate the complications inherent in understanding and assessing official apologies. In both cases, it is not clear that success or failure in apologizing is something that can be drawn from the text itself or even its ceremonial context - some serious concerns cannot be resolved within the space of a speech or a text, and will very much depend on what happens next for Canada and Australia's indigenous peoples. And yet, the significance and meaning of the apology as performed text does not disappear when we acknowledge this. The various strengths and weaknesses of both apologies highlighted here do matter and have mattered to those who received them and those who witnessed them. Identifying how these strengths and weaknesses play out along axes of narrative, disavowal and commitment - even while recognizing that these shift and overlap, according to each particular circumstance - goes some way towards untangling and deciphering the meaning, the relative successes and the shortcomings of both. Reorienting our approach to apologies in this way allows us to see tremendous potential in these two recent apologies, without assuming that potential has come close to fulfillment.

\section{List of References}

Arendt, Hannah. 1958. The Human Condition, $2^{\text {nd }}$ ed. Chicago: University of Chicago Press. Austin, J.L. 1975. How to do Things with Words. Oxford: Oxford University Press.

Bavelas, Janet. 2004. An Analysis of Formal Apologies By Canadian Churches to First Nations. Occasional Paper presented to the Centre for Studies in Religion and Society, University of Victoria. web.uvic.ca/psyc/bavelas/2004ChurchApol.pdf. Accessed 4 November 2011.

Bell, Macalester. 2008. Forgiving Someone for Who They Are (and Not Just What They've Done). Philosophy and Phenomenological Research 77 (3): 625-658.

1997. Bringing them Home: Report of the National Inquiry into the Separation of Aboriginal and Torres Strait Islander Children from Their Families.

http://www.humanrights.gov.au/Social Justice/bth report/report/index.html. Accessed 4 November 2011.

Busby, Cathy. Sorry. www.cathybusby.ca. Accessed March 17, 2009.

Campbell, Sue. Challenges to Memory in Political Contexts: Recognizing Disrespectful Challenges. Discussion Paper for the Indian Residential Schools Resolution Canada, Truth and Reconciliation Commission (obtained from private correspondence).

Card, Claudia. 2007. Genocide and Social Death. In Claudia Card and Armen T. Marsoobian, Genocide's Aftermath: Responsibility and Repair. New York: Blackwell.

Cunningham, Michael. 2004. Apologies in Irish Politics: A Commentary and Critique. Contemporary British History 18 (4): 80-92. 
Davis, Paul. 2002. On apologies. Journal of Applied Philosophy 19 (2): 169-173.

Dueck, Lorna. 2000. Sorry Isn't Good Enough. Globe and Mail. October 31. http://www.listenuptv.com/lorna/native.htm. Accessed 18 March 2009.

Fontaine, Phil, Chief of the Assembly of First Nations. Response to Canadian Government Apology, June 11, 2008.

http://www2.canada.com/vancouversun/news/story.html?id=18133d91-b8aa-4fbe-956e20298d79c1d5. Accessed 18 March 2009.

2008. Justice, Responsibility, and reconciliation: Legacies of the Holocaust and the Persecution of Aboriginal Canadians. Talk given at Ryerson University as part of Holocaust Awareness Week, November 3, 2008.

Fricker, Miranda. 2003. Epistemic Justice and a Role for Virtue in the Politics of Knowing. Metaphilosophy 34 (1-2) (January 1): 154-173.

Gibney, Mark, and Erik Roxstrom. 2001. The Status of State Apologies. Human Rights Quarterly 23 (4): 911-939.

Gibney, Mark, Rhoda E. Howard-Hassmann, Jean-Marc Coicaud, and Niklaus Steiner. 2007. The Age of Apology: Facing Up to the Past. University of Pennsylvania Press, October 24.

Gill, Kathleen. 2000. The Moral Functions of an Apology. The Philosophical Forum 31 (1) (March): 11-27.

Govier, Trudy, and Wilhelm Verwoerd. 2002. The Promise and Pitfalls of Apology. Journal of Social Philosophy 33 (1): 67-82.

Griswold, Charles. 2007. Forgiveness: a philosophical exploration. Cambridge: Cambridge University Press.

Harper, Stephen, Right Honourable, Prime Minister of Canada. 2008. Statement of Apology to former students of Indian Residential Schools. June 11.www.fns.bc.ca/pdf/TextofApology.pdf . Accessed 4 November 2011.

Canada, and René Dussault. 1996. People to people, nation to nation: highlights from the report of the Royal Commission on Aboriginal Peoples. [Ottawa]: The Commission.

Indian Residential Schools Settlement Agreement.

http://www.residentialschoolsettlement.ca/settlement.html. Accessed 4 November 2011.

King, Thomas. 2003. The Truth About Stories: A Native Narrative. Toronto: Anansi Press.

Kort, Louis F. "What is an Apology?" Philosophy Research Archives 1 (2975) 80-87.

Lazare, Aaron. 2004. On Apology. Oxford: Oxford University Press.

Llewellyn, Jennifer J. 2002. Dealing with the Legacy of Native Residential Schools in Canada: Litigation, ADR, and Restorative Justice. University of Toronto Law Journal 52: 253-300.

MacDuff, Anne. 2008. Do Sorry Statements Make You Liable? The Australian Legal Context. Forgiveness: Probing the Boundaries (First Global Conference), Salzburg, Austria.

Metcalfe, Robin. 2005. Up Close and Personal. In Sorry, ed. Cathy Busby. Halifax: St Mary's Art Gallery.

Moon, Claire. 2004. Prelapsarian State: Forgiveness and Reconciliation in Transitional Justice. International Journal for the Semiotics of Law 17 (2004) 185-197.

Murphy, Rex. 2008. "The Day the House Stood Still." Globe and Mail, Saturday June 14.

Nelson, Brendan, Leader of the Australian Liberal Party. 2008. "Response to Government Apology." February 13. Reprinted online in The Australian http://www.theaustralian.news.com.au/story/0,25197,23206522-5013172,00.html. Accessed 17 March 2009.

Nobles, Melissa. 2008. The Politics of Official Apologies. Cambridge: Cambridge University Press.

Prager, Carol Anne Leuchs, and Trudy Govier. 2003. Dilemmas of reconciliation: cases and concepts. Wilfrid Laurier Univ. Press.

Rolfsen, Catherine. 2008. After The Apology. This Magazine. September/October.

Rudd, Kevin, Right Honourable, Prime Minister of Australia. 2008. Apology to Australia's Indigenous Peoples. February 13. www.aph.gov.au/house/rudd speech.pdf. Accessed 18 March 2009. 
Salutin, Rick. 2008. Issues of Apology and Power. Globe and Mail. Friday June 13.

Smith, Andrea. 2005. Conquest: Sexual Violence and the American Indian Genocide. Cambridge: South End Press.

Smith, Nick. 2008. I Was Wrong: The Meaning of Apologies. Cambridge: Cambridge University Press.

Solomon, Deborah. 2004. The Way We Live Now: Questions for Kenneth Pollack. New York Times Magazine. October 24.

http://query.nytimes.com/gst/fullpage.html?res=9902E4DC103AF937A15753C1A9629C8B6 3. Accessed 18 March 2009.

'Sorry': the unfinished business of the Bringing Them Home report" Background Note. Parliamentary Library, National Parliament of Australia.

http://www.aph.gov.au/Library/pubs/BN/2007-08/BringingThemHomeReport.htm. Accessed 12 March 2009.

Spelman, Elizabeth. 2002. Repair: The Impulse to Restore in a Fragile World. Boston: Beacon Press.

Stewart, Jane, Honourable, Minister of Indian and Northern Affairs. 1998. Statement of Reconciliation on behalf of Canada's Government to Canada's Aboriginal Peoples. January 7. http://www.deal.org/content/index.php?option $=$ com content\&task=view\&id=889\&Itemid=1 082. Accessed 18 March 2009.

Tavuchis, Nicolas. 1990. Mea Culpa: A Sociology of Apology and Reconciliation. Stanford: Stanford University Press.

Thompson, Janna. 1992. Taking Responsibility for the Past: Reparations and Historical Injustice. Cambridge: Polity Press.

2008. Apology, Justice and Respect: A Critical Defense of the Political Apology. In The Age of Apology: Facing Up to the Past, edited by Mark Gibney et al. Philadelphia: University of Pennsylvania Press.

Waldron, Jeremy. 1992. The Supercession of Historical Injustice. Ethics 103 (1): 4-28.

Weyeneth, Robert R. 2001. The Power of Apology and the Process of Historical Reconciliation. The Public Historian 23 (3): 9-30. 